Gynecologic and

Obstetric Investigation
Gynecol Obstet Invest 2009;67:269-274

DOI: 10.1159/000210373
Received: August 7, 2008

Accepted after revision: December 9, 2008 Published online: April 1, 2009

\title{
Effects of Progesterone and Its Antagonist Mifepristone on Progesterone Receptor A Expression in Human Umbilical Vein Endothelial Cells
}

\author{
Bettina Toth $^{a}$ Christoph Scholz ${ }^{b}$ Robert Ochsenkühn ${ }^{a}$ Sandra Schulze ${ }^{b}$ \\ Christina Kuhn $^{b}$ Klaus Friese ${ }^{a, b}$ Udo Jeschke ${ }^{b}$ \\ ${ }^{\mathrm{a}}$ Department of Obstetrics and Gynecology, Grosshadern, ${ }^{\mathrm{b}}$ Department of Obstetrics and Gynecology, \\ Innenstadt, Ludwig Maximilians University, Munich, Germany
}

\section{Key Words}

Human umbilical vein endothelial cells • Progesterone

receptor $\mathrm{A}$ and $\mathrm{B} \cdot$ Progesterone receptor antagonist

\begin{abstract}
Effects of female steroid hormones on endothelial cells are gaining increased importance due to several studies on the effects of hormonal treatment on cardiovascular risk. Recent data argue for an improvement of endothelium-derived relaxation and impaired vascular contraction by estradiol, whereas progesterone and testosterone might entail contrary effects. So far, gestagenic influence on endothelial cell physiology is poorly understood. Human umbilical vein endothelial cells (HUVECs) exposed to the female sex hormones estradiol and progesterone show expression of estrogen receptor- $\beta(E R \beta)$ and progesterone receptor $A(P R-A)$, and are negative for $E R \alpha$ and PR-B. The aim of this study was to analyze the expression and stimulation of PR-A and -B in HUVEC s after stimulation with progesterone and PR antagonists that are commercially available. PR-B expression or upregulation was abrogated after application of progesterone or antagonists to HUVECs. Expression of PR-A could be significantly upregulated with progesterone and mifepristone. Unexpectedly, stimulation with the progesterone antago-
\end{abstract}

nist RU486 (mifepristone) was accomplished by an upregulation of PR-A expression in our study. We conclude that gestagenic effects on HUVECs independent of modulators are mediated via the PR-A.

Copyright $\odot 2009$ S. Karger AG, Basel

\section{Introduction}

Vascular endothelial cells are involved in the regulation of angiogenesis, inflammatory responses, vascular tone and permeability. Impaired endothelial function leads to increased cardiovascular risk [1]. In females, endothelial dysfunction gradually ensues after the menopause [2], and is associated with disturbed dilatation [3], decline in endothelial nitric oxide synthase (eNOS) activity and nitric oxide (NO) bioavailability as well as abnormal endothelial morphology $[4,5]$. These functional alterations of endothelial cells contribute to the increased risk of cardiovascular diseases seen in postmenopausal women [6]. The incidence of coronary heart disease (CHD) in premenopausal women is significantly lower

B.T. and C.S. contributed equally to this study.

\section{KARGER}

Fax +4161306 1234 E-Mail karger@karger.ch www.karger.com (c) 2009 S. Karger AG, Basel

0378-7346/09/0674-0269\$26.00/0

Accessible online at:

www.karger.com/goi
PD Dr. Udo Jeschke

Department of Obstetrics and Gynecology, Maistrasse

Ludwig Maximilians University, Maistrasse 11, DE-80337 Munich (Germany)

Tel. +49895160 4266, Fax +498951604916

E-Mail udo.jeschke@med.uni-muenchen.de 
than in age-matched men with similar risk profiles and increases after menopause [7-9].

With regard to hormonal treatment (HT) in postmenopausal women, progesterone is generally co-administered with estrogen to prevent endometrial cancer by opposing the proliferative effect of estrogens. So far, the influence of the administered progestagens on cardiovascular function and development of atherosclerosis remains controversial $[10,11]$. However, HT has been regarded as an effective tool to protect postmenopausal women from CHD [12]. Until now, major randomized clinical trials have failed to confirm the cardiovascular advantages of HT [13].

The Heart and Estrogen/Progestin Replacement Study showed that the co-administration of medroxyprogesterone acetate (MPA) with conjugated equine estrogen (CEE) did not reduce the rate of events in postmenopausal women with established CHD, yet the treatment did increase the rate of thromboembolic events and gallbladder disease [14-18].

The Women's Health Initiative trial showed that HT combined with CEE and MPA was associated with a nonsignificant increase in CHD in postmenopausal women, whereas women in the sister cohort, receiving CEE alone, showed a nonsignificant decrease in coronary events, along with a significant reduction in a composite outcome of CHD events in younger women $[19,20]$.

However, progesterone or other synthetic progestins have variable influences on endothelial function. For example, natural progesterone increases endothelial NO production, whereas MPA is devoid of such action [21]. In nonhuman primates, MPA has been shown to interfere with the atheroprotective effects of estrogens, which was not encountered with natural progesterone $[22,23]$. In support of these observations, discrepant effects of progestins have also been described in other tissues [24].

A diversity of progesterone receptor (PR) activators and inhibitors exists with different potential to bind to PR-A, PR-B or both. In our study, we analyzed the expression of PR-A and PR-B in human umbilical vein endothelial cells (HUVECs) after stimulation with progesterone and its antagonist mifepristone with specific monoclonal antibodies by immunocytochemistry.

\section{Material and Methods}

\section{Cell Culture}

HUVECs were obtained from Promocell (Heidelberg, Germany) at passage 2 or 3 . The cells were cultivated in phenol red free endothelial cell growth medium (ECGM) (Customer formula-
Table 1. Substances used for stimulation of PR-A

\begin{tabular}{lll}
\hline Substance & Dilution & Source \\
\hline Progesterone, $\mathrm{nmol} / \mathrm{ml}$ & $0.1-100$ & Sigma-Aldrich \\
Mifepristone, $\mathrm{nmol} / \mathrm{ml}$ & $0.1-100$ & Roussel-Uclaf \\
\hline
\end{tabular}

tion, Promocell, Heidelberg, Germany). ECGM contained 10\% fetal bovine serum, $1.0 \mathrm{mg} / \mathrm{ml}$ hydrocortisone, $0.1 \mathrm{ng} / \mathrm{ml}$ endothelial growth factor, $1.0 \mathrm{ng} / \mathrm{ml}$ basic fibroblast growth factor and $2 \mathrm{ml}$ endothelial cell growth substrate as well as $5 \mathrm{ml}$ streptomycin (Biochrom AG, Berlin, Germany) and $5 \mathrm{ml}$ amphotericin B (Biochrom) in $500 \mathrm{ml}$ medium.

HUVECs were used for experiments between passages 3 and 4 . All cell cultures were maintained in a humidified $5 \% \mathrm{CO}_{2}$ atmosphere at $37^{\circ} \mathrm{C}$. HUVECs were incubated with progesterone and mifepristone in different concentrations $(0-100 \mathrm{nmol} / \mathrm{ml}$; table 1) and cultivated for up to $72 \mathrm{~h}$ on chamber slides (Nunc, Wiesbaden, Germany). These concentrations are related to physiological progesterone concentrations in pregnant human females. Cells were fixed with methanol/ethanol (50/50\%; Merck, Darmstadt, Germany). The Human Investigation Review Board of the Ludwig Maximilian University Munich approved the study.

\section{Immunocytochemistry}

Expression of PR-A was analyzed by using a specific monoclonal antibody (1A6, Mouse IgG1, 1:50, Immunotech, Prague, Czech Republic) and the ABC staining method (Vectastain Elite mouseIgG-Kit, Vector, Burlingame, Calif., USA). Staining intensity was graded by using a semiquantitative score by counting the absolute percentage of positive-stained cells.

Two blinded, independent observers evaluated the specific immunocytochemical staining reaction without knowing the prior evaluation of each specimen. In each condition, 6-9 independent specimens were taken and evaluated independently.

In brief, HUVECs were cultivated under sterile conditions in chamber slide cultures Quadriperm (Nunc) for up to $72 \mathrm{~h}$, dried, wrapped and stored at $-80^{\circ} \mathrm{C}$ as described earlier [25]. After thawing, cells were briefly fixed with formalin (Merck; $5 \%$ in PBS, $5 \mathrm{~min}$ ). Slides were incubated in methanol $/ \mathrm{H}_{2} \mathrm{O}_{2}(30 \mathrm{~min})$ to inhibit endogenous peroxidase activity, washed in $\mathrm{PBS}$ ( $5 \mathrm{~min})$ and treated with goat serum (20 min, room temperature, $\mathrm{RT})$ to reduce nonspecific background staining. Incubation with the primary anti-PR-A antibody (1A6, Mouse IgG1, 1:50, Immunotech) was done overnight at $4^{\circ} \mathrm{C}$. Sections were then incubated with the biotinylated secondary anti-mouse antibody ( $1 \mathrm{~h}, \mathrm{RT}$ ) and avidin-biotinylated peroxidase (45 min, RT). Between each step, the sections were washed with PBS (pH 7.4), three times. Peroxidase staining reaction was done with diaminobenzidine $/ \mathrm{H}_{2} \mathrm{O}_{2}(1 \mathrm{mg} / \mathrm{ml} ; 5 \mathrm{~min})$ and stopped in tap water (10 min). Sections were counterstained in hematoxylin (1 min) and then coverslipped. In controls, the primary antibody was replaced with preimmune mouse serum. Positive (MCF-7 breast cancer cell line) and negative control cells (MDA-MB231), both from American Type Culture Collection (Manassas, Va., USA), for PR-A staining were always included. The slides were finally
Toth/Scholz/Ochsenkühn/Schulze/ Kuhn/Friese/Jeschke 

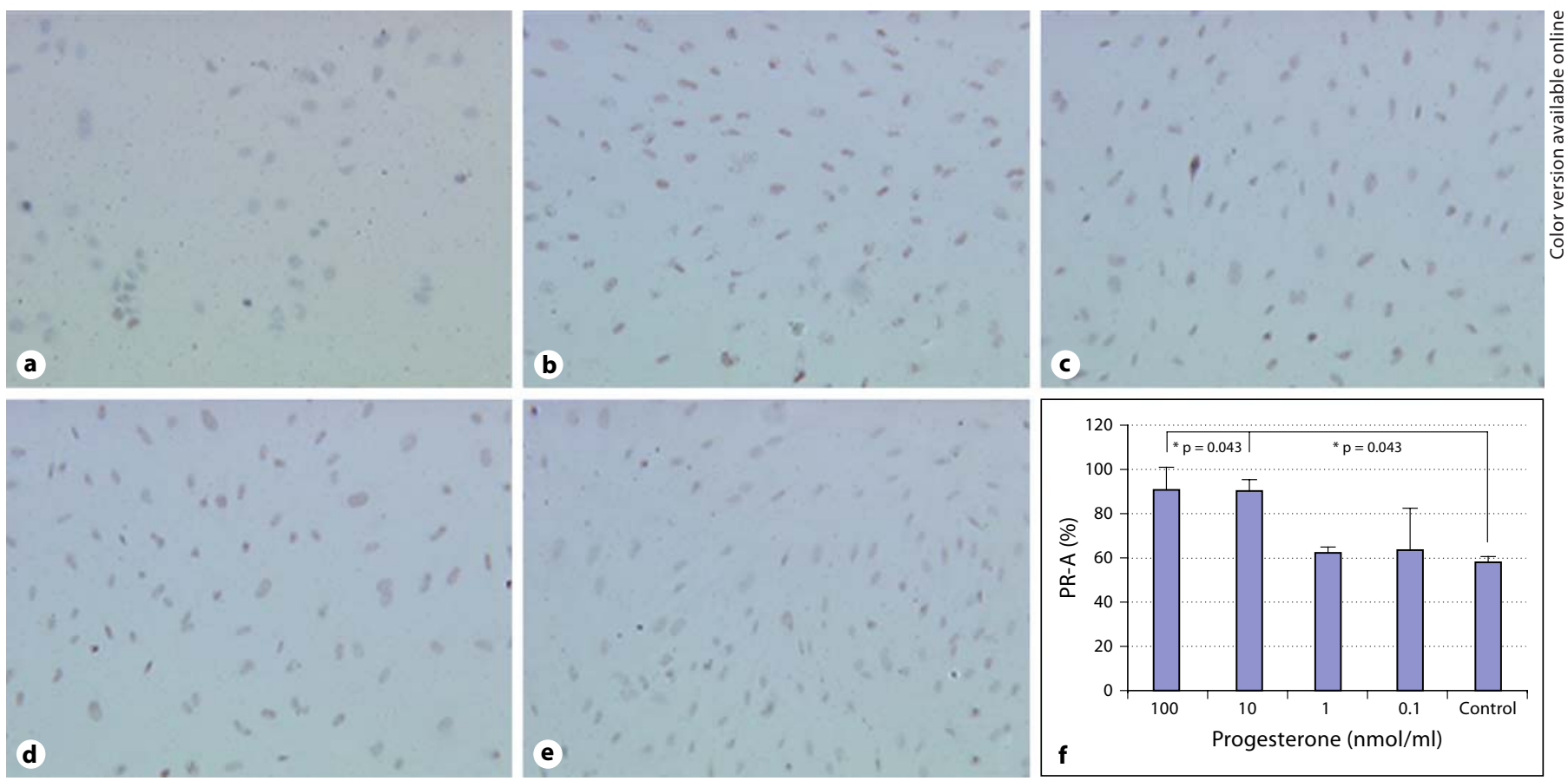

Fig. 1. a PR-A expression in unstimulated HUVECs. $\times 10$. b PR-A expression in HUVECs after $0.1 \mathrm{nmol} / \mathrm{ml}$ stimulation with progesterone. $\times 10$. c PR-A expression in HUVECs after $1.0 \mathrm{nmol} /$ $\mathrm{ml}$ stimulation with progesterone. $\times 10$. d PR-A expression in
HUVECs after $10 \mathrm{nmol} / \mathrm{ml}$ stimulation with progesterone. $\times 10$. e PR-A expression in HUVECs after $100 \mathrm{nmol} / \mathrm{ml}$ stimulation with progesterone. $\times 10$. $f$ PR-A expression in HUVECs after incubation with progesterone. embedded in mounting buffer and examined with a Zeiss Axiophot photomicroscope (Carl Zeiss, Jena, Germany). The extent of PR expression was determined in a blinded fashion in one run with identical staff, equipment, and chemicals.

From each section, 5 digital pictures were taken at random of different places of stained HUVECs ( $\times 200$ magnification; 3CCD color camera; Axiocam) and examined with a Zeiss Axiophot photomicroscope.

\section{Statistics}

The SPSS/PC software package (SPSS, Chicago, Ill., USA) version 15.0 and 16.0 was used for collection, processing, and statistical data analysis. Statistical analysis was performed using the nonparametric Mann-Whitney U signed rank test for comparison of the means. $\mathrm{p}<0.05$ values were considered statistically significant.

\section{Results}

\section{Progesterone}

Progesterone acts as a natural PR ligand (PR-A, PR-B). HUVECs stimulated with $100 \mathrm{pmol} / \mathrm{ml}$ and 1, 10, and 100 $\mathrm{nmol} / \mathrm{ml}$ progesterone, respectively, showed expression of PR-A after cultivation for up to $72 \mathrm{~h}$ (fig. 1a-e). Significantly elevated PR-A expression could be observed by administration of 10 and $100 \mathrm{nmol} / \mathrm{ml}$ progesterone, as described ( $p<0.05$; fig. 1f).

\section{Mifepristone}

Unexpectedly, administration of the PR antagonist RU486 led to an upregulation of PR-A expression. HUVECs stimulated with 1,10 , and $100 \mathrm{nmol} / \mathrm{ml} \mathrm{mife-}$ pristone showed significant upregulation of PR-A in all cases compared with nonstimulated controls $(\mathrm{p}<0.05$, respectively; fig. 2).

\section{Discussion}

Recently, basic findings on the expression of estrogen receptor (ER) and PR in HUVECs were published, indicating the lack of ER $\alpha$ and PR-B expression in HUVECs [25].

In our study, we were able to demonstrate that progesterone acts as an activator on endothelial cells and is able 

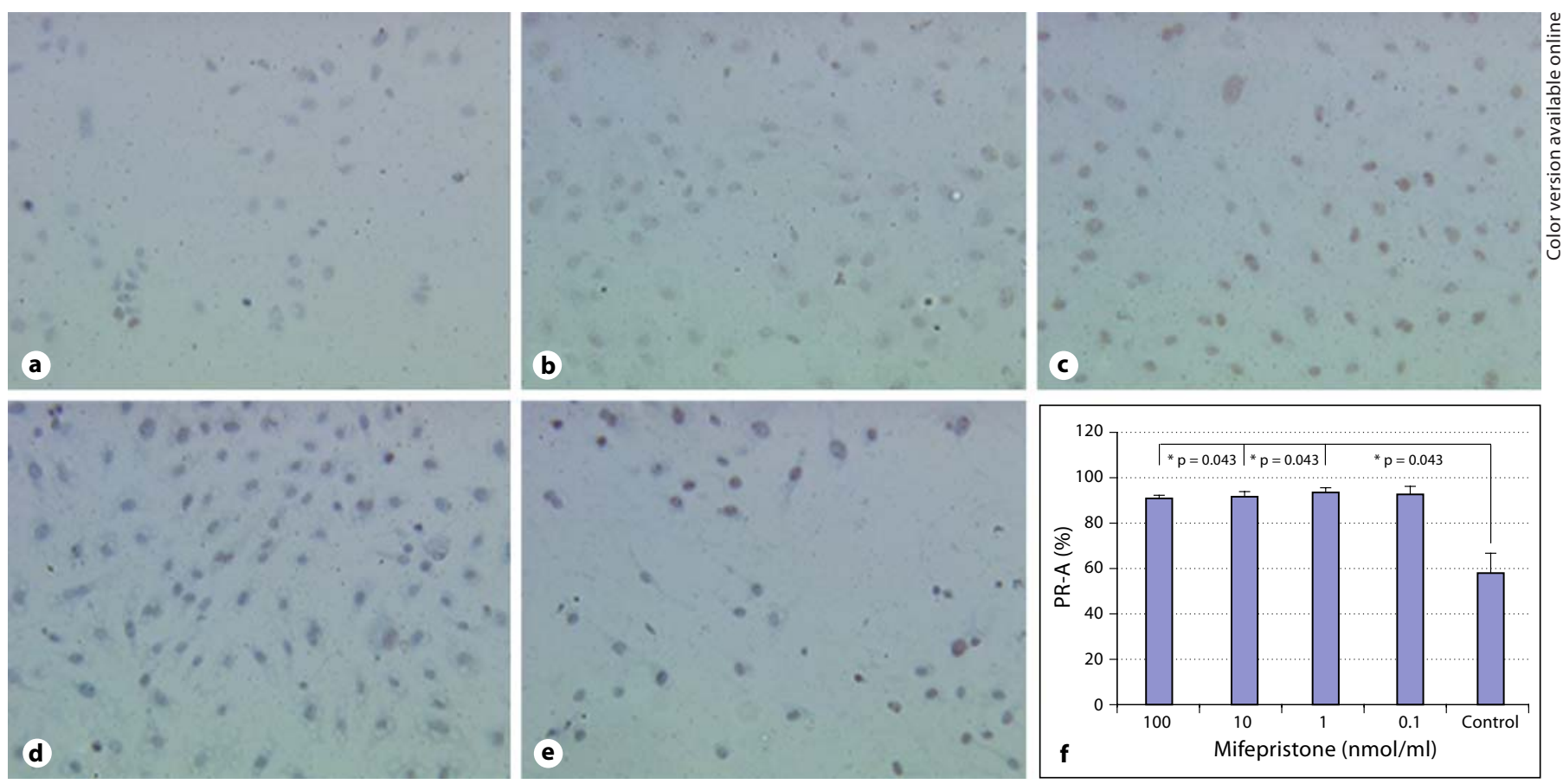

Fig. 2. a PR-A expression in unstimulated HUVECs. $\times 10$. b PR-A expression in HUVECs after $0.1 \mathrm{nmol} / \mathrm{ml}$ stimulation with mifepristone. $\times 10$. c PR-A expression in HUVECs after $1.0 \mathrm{nmol} /$ $\mathrm{ml}$ stimulation with mifepristone. $\times 10$. d PR-A expression in
HUVECs after $10 \mathrm{nmol} / \mathrm{ml}$ stimulation with mifepristone. $\times 10$. e PR-A expression in HUVECs after $100 \mathrm{nmol} / \mathrm{ml}$ stimulation with mifepristone. $\times 10$. $\mathbf{f}$ PR-A expression in HUVECs after incubation with mifepristone. to upregulate PR-A expression in a dose-dependent manner. In contrast to former studies, PR antagonist RU486 also led to an upregulation of PR-A expression.

The cellular effects of gestagens are mediated by binding to nuclear receptors (PR) which activate transcription of genes involved in cellular growth control. So far, endothelial effects of gestagens are poorly understood and, as compared with data on estrogenic influences on endothelial cells, also poorly investigated. Fu et al. [26] investigated effects of progesterone and MPA on actin remodeling, moesin activation and cell movement in human endothelial cells. They were able to show that both gestagens regulate endothelial cell movement by rapidly signaling to the actin-binding protein moesin and to the actin cytoskeleton.

To further study the effects of gestagens on vascular function, Hermenegildo et al. [27] studied the effects of progesterone and MPA on prostacyclin production in HUVECs. Both gestagens significantly increased prostacyclin release in a time- and dose-dependent manner by enhancing Cox-1 and Cox-2 expression and activities.
In contrast to our recent findings on the lack of PR-B expression on HUVECs, Tatsumi et al. [28] described PR$A$ and PR-B mRNA expression on HUVECs. The authors investigated the effect of progesterone, MPA, norethindrone acetate, levonorgestrel as well as dienogest on cytokine-stimulated HUVEC expression of adhesion molecules. However, progesterone or dienogest did not affect IL-1ß-stimulated ICAM-1 or VCAM-1 expression, whereas the other gestagens did.

Additionally, concomitant addition of mifepristone blocked the gestagen-induced increase in adhesion molecules. They concluded that dienogest unlike other synthetic progestins lacks the stimulatory effect on cell adhesion molecules [28]. We were able to show that HUVEC stimulation with increasing amounts of RU486 leads to an upregulation of PR-A in a dose-dependent manner. Our data implicate that RU486 only acts as a PR antagonist in the presence of PR activators like progestone.

The Women's Health Initiative trial reported an excess of heart diseases in postmenopausal women receiving MPA. Therefore, Simoncini et al. [21] investigated the effects of progesterone, MPA, dydrogesterone and its me- 
tabolite 20-a-dihydrogesterone on endothelial synthesis of $\mathrm{NO}$, and characterized the signaling events recruited by these compounds. In contrast to dydrogesterone, progesterone and 20-a-dihydrogesterone, MPA did not trigger eNOS enzymatic activation and decreased the extent of eNOS induction by estradiol. The authors concluded that their findings support the concept that synthetic progestins act differently on vascular cells and that hormonal preparations may differ in their cardiovascular effects [29].

Studies on the effects of HT in postmenopausal women indicate procoagulant effects of gestagens and estrogens. To further study the effects of gestagens on hemostasis, Zerr-Fouineau et al. [30] investigated whether progestins affect the formation of NO in endothelial cells and examined the underlying mechanism.
Certain progestins, including MPA, reduced the antiaggregatory effect of endothelial cells by decreasing the expression of eNOS and the formation of NO in endothelial cells; an effect that is mediated via activation of glucocorticoid receptors.

In summary, our study showed that progesterone is able to upregulate PR-A expression in a dose-dependent manner and that the PR antagonist mifepristone also acts as a PR activator when administered solely.

\section{Acknowledgements}

This study is part of the doctoral thesis of Gitti Saadat and Alrun Geller. Bettina Toth was supported by 'Friedrich Baur-Stiftung', 'Förderung für Forschung und Lehre', 'Hochschul-Wissenschafts-Programm' and LMU Excellent Mentoring Program, Ludwig Maximilians University, Munich, Germany.

\section{References}

1 Feletou M, Vanhoutte PM: Endothelial dysfunction: a multifaceted disorder (The Wiggers Award Lecture). Am J Physiol Heart Circ Physiol 2006;291:H985-H1002.

2 Taddei S, Virdis A, Ghiadoni L, Mattei P, Sudano I, Bernini G, Pinto S, Salvetti A: Menopause is associated with endothelial dysfunction in women. Hypertension 1996;28: 576-582.

3 Herrington D: Role of estrogens, selective estrogen receptor modulators and phytoestrogens in cardiovascular protection. Can J Cardiol 2000;16(suppl E):5E-9E.

4 Kublickiene K, Svedas E, Landgren BM, Crisby M, Nahar N, Nisell H, Poston L: Small artery endothelial dysfunction in postmenopausal women: in vitro function, morphology, and modification by estrogen and selective estrogen receptor modulators. J Clin Endocrinol Metab 2005;90:6113-6122.

5 Majmudar NG, Robson SC, Ford GA: Effects of the menopause, gender, and estrogen replacement therapy on vascular nitric oxide activity. J Clin Endocrinol Metab 2000;85: 1577-1583.

6 Kannel WB: The Framingham study. BMJ 1976;2:1255.

7 Low AK, Russell LD, Holman HE, Shepherd JM, Hicks GS, Brown CA: Hormone replacement therapy and coronary heart disease in women: a review of the evidence. Am J Med Sci 2002;324:180-184.

8 Gouva L, Tsatsoulis A: The role of estrogens in cardiovascular disease in the aftermath of clinical trials. Hormones (Athens) 2004;3: 171-183.
9 Rosano GM, Vitale C, Fini M: Hormone replacement therapy and cardioprotection: what is good and what is bad for the cardiovascular system? Ann NY Acad Sci 2006; 1092:341-348

10 Rossouw JE, Anderson GL, Prentice RL, LaCroix AZ, Kooperberg C, Stefanick ML, Jackson RD, Beresford SA, Howard BV, Johnson KC, Kotchen JM, Ockene J: Risks and benefits of estrogen plus progestin in healthy postmenopausal women: principal results From the Women's Health Initiative randomized controlled trial. JAMA 2002; 288:321-333.

11 Lemay A: The relevance of the Women's Health Initiative results on combined hormone replacement therapy in clinical practice. J Obstet Gynaecol Can 2002;24:711715.

12 Barrett-Connor E, Bush TL: Estrogen and coronary heart disease in women. JAMA 1991;265:1861-1867.

13 Manson JE, Hsia J, Johnson KC, Rossouw JE, Assaf AR, Lasser NL, Trevisan M, Black HR, Heckbert SR, Detrano R, Strickland OL, Wong ND, Crouse JR, Stein E, Cushman M: Estrogen plus progestin and the risk of coronary heart disease. N Engl J Med 2003;349: 523-534.

14 Tannen RL, Weiner MG, Xie D, Barnhart K: A simulation using data from a primary care practice database closely replicated the women's health initiative trial. J Clin Epidemiol 2007;60:686-695.
15 Sharma S: Hormone replacement therapy in menopause: current concerns and considerations. Kathmandu Univ Med J 2003;1:288293.

16 Tansavatdi K, McClain B, Herrington DM: The effects of smoking on estradiol metabolism. Minerva Ginecol 2004;56:105-114.

17 Bagchi D, Das DK, Tosaki A, Bagchi M, Kothari SC: Benefits of resveratrol in women's health. Drugs Exp Clin Res 2001;27:233248.

18 Dhiman RK, Chawla YK: Is there a link between oestrogen therapy and gallbladder disease? Expert Opin Drug Saf 2006;5:117129.

19 Hsia J, Langer RD, Manson JE, Kuller L, Johnson KC, Hendrix SL, Pettinger M, Heckbert SR, Greep N, Crawford S, Eaton CB, Kostis JB, Caralis P, Prentice R: Conjugated equine estrogens and coronary heart disease: the Women's Health Initiative. Arch Intern Med 2006;166:357-365.

20 Vickers MR, Martin J, Meade TW: The Women's international study of long-duration oestrogen after menopause (WISDOM): a randomised controlled trial. BMC Womens Health 2007;7:2.

21 Simoncini T, Mannella P, Fornari L, Caruso A, Willis MY, Garibaldi S, Baldacci C, Genazzani AR: Differential signal transduction of progesterone and medroxyprogesterone acetate in human endothelial cells. Endocrinology 2004; 145:5745-5756.

22 Adams MR, Clarkson TB, Shively CA, Parks JS, Kaplan JR: Oral contraceptives, lipoproteins, and atherosclerosis. Am J Obstet Gynecol 1990;163:1388-1393. 
23 Adams MR, Register TC, Golden DL, Wagner JD, Williams JK: Medroxyprogesterone acetate antagonizes inhibitory effects of conjugated equine estrogens on coronary artery atherosclerosis. Arterioscler Thromb Vasc Biol 1997; 17:217-221.

24 Nilsen J, Brinton RD: Divergent impact of progesterone and medroxyprogesterone acetate (Provera) on nuclear mitogen-activated protein kinase signaling. Proc Natl Acad Sci U S A 2003;100:10506-10511.

25 Toth B, Saadat G, Geller A, Scholz C, Schulze $S$, Friese K, Jeschke U: Human umbilical vascular endothelial cells express estrogen receptor beta (ERbeta) and progesterone receptor A (PR-A), but not ERalpha and PR-B. Histochem Cell Biol 2008;130:399-405.
26 Fu XD, Flamini M, Sanchez AM, Goglia L, Giretti MS, Genazzani AR, Simoncini T: Progestogens regulate endothelial actin cytoskeleton and cell movement via the actinbinding protein moesin. Mol Hum Reprod 2008;14:225-234

27 Hermenegildo C, Oviedo PJ, Garcia-Perez MA, Tarin JJ, Cano A: Effects of phytoestrogens genistein and daidzein on prostacyclin production by human endothelial cells. J Pharmacol Exp Ther 2005;315:722-728.

28 Tatsumi H, Kitawaki J, Tanaka K, Hosoda T, Honjo H: Lack of stimulatory effect of dienogest on the expression of intercellular adhesion molecule-1 and vascular cell adhesion molecule-1 by endothelial cell as compared with other synthetic progestins. Maturitas 2002;42:287-294.
29 Simoncini T, Caruso A, Giretti MS, Scorticati C, Fu XD, Garibaldi S, Baldacci C, Mannella P, Fornari L, Genazzani AR: Effects of dydrogesterone and of its stable metabolite, 20-alpha-dihydrodydrogesterone, on nitric oxide synthesis in human endothelial cells. Fertil Steril 2006;86(suppl 4):1235-1242.

30 Zerr-Fouineau M, Chataigneau M, Blot C, Schini-Kerth VB: Progestins overcome inhibition of platelet aggregation by endothelial cells by down-regulating endothelial NO synthase via glucocorticoid receptors. FASEB J 2007;21:265-273.
Toth/Scholz/Ochsenkühn/Schulze/ Kuhn/Friese/Jeschke 